\title{
Orthodoxa Confessio? Konfessionsbildung, Konfessionalisierung und ihre Folgen in der östlichen Christenheit Europas, hrsg. von Mihai-D. Grigore, Florian Kührer-Wielach (Göttingen: Vandenhoeck \& Ruprecht, 2018), 359 s. (Veröffentlichungen des Instituts für Europäische Geschichte Mainz. Band 114)*
}

У видавничій серії Інституту європейської історії ім. Ляйбніца у Майнці (Leibniz-Institut für Europäische Geschichte) опубліковано як 114-й том збірник про конфесіоналізацію у східнохристиянських традиціях Південної та Східної Європи. Це матеріали конференції (доповнені іншими текстами), що відбулася 5-7 березня 2015 р. у Майнці, а також результат спільного наукового проекту щойно згаданого Інституту з Інститутом німецької культури й історії Південної Європи Мюнхенського університету Людвіга-Максиміліана (Institut für deutsche Kultur und Geschichte Südosteuropas an der LMU München). Збірник складається із вступу упорядників та 12 статей, розподілених на дві частини - теоретичну (чи методологічну) й емпіричну (дослідження на конкретних прикладах). Авторами наукових розвідок $є$ богослови, історики християнства, візантиністи, історики культури, філологи тощо здебільшого з німецьких наукових установ, а також голландського та румунського університетів.

Збірник відкриває програмова стаття редакторів-упорядників д-ра Михая ді Грігоре та д-ра Флоріана Кюрера-Віляха, працівників відділу західної релігійної історії Інституту європейської історії

* Рецензію написано за підтримки баварської фундації BAYHOST у рамках наукового стажування в Інституті Східних Церков Вюрцбурзького університету ім. Юліуса Максиміліана / Ostkirchliches Institut, Julius-MaximiliansUniversität Würzburg (Вюрцбург, Німеччина). 
ім. Ляйбніца у Майнці та Інституту німецької культури та історії Південної Європи Мюнхенського університету відповідно. Сформульована тут основна мета книжки - це з'ясувати, наскільки концепти конфесіоналізації (Konfessionalisierung) та конфесійного будування (Konfessionsbildung) є застосовними/придатними не лише для вивчення латинських християнських традицій, але й для східнохристиянських церков, передусім православних, Східної та Південної Європи (с. 9). Зокрема, автори зауважують брак теоретичної бази та рефлексії про «православну Європу» у німецькомовній історіографії (с. 11). Оскільки хронологічними рамками для книжки слугує період від епохи пізнього Середньовіччя до першої половини XX ст., тому наголошено на тезі про дві конфесіоналізації - ранньомодерну та модерну (с. 13). Далі окреслено три основні питання збірника: 1) чи у випадку східнохристиянських традицій, зокрема Православної Церкви, громади вірян можна розглядати як власне «конфесії; 2) на яких термінологічних та концептуальних засадах варто застосовувати парадигму конфесіоналізації щодо східних Церков; 3) якою може бути періодизація цих концептів стосовно східнохристиянських традицій (с. 13). Таким чином, у центрі уваги дослідників - вивчення процесів конфесіоналізації та конфесійного будування у православних, а також почасти унійних церквах Східної та Південної Європи. Варто зауважити, що упорядники чітко не визначають географічні рамки дослідження та не уточнюють, які саме терени вони розуміють під поняттям «die östliche Christenheit».

Методологічну частину книжки розпочинає есей професорки відділу західної релігійної історії Ірене Дінгель з Інституту європейської історії ім. Ляйбніца у Майнці. Привертає увагу те, що авторка використовує на позначення конфесійного будування термін Bekenntnisbildung замість Konfessionsbildung. У есеї здійснено спробу у порівняльній перспективі та на методологічному рівні показати відмінності між поняттями «формування конфесій» та «конфесіоналізація» (с. 23). Насамперед, на прикладі католицької та протестантської Європи коротко представлено історіографічний розвиток та проблематику парадигми «конфесіоналізація». Початки концепту, як зазначає дослідниця, заклали праці науковця з Тюбінгена Ернста Вальтера Цеедена, зокрема його монографія «Заснування та форми конфесійної освіти в епоху релігійного 
протистояння» (1965). Кристалізація ж концептуальних засад парадигми припадає на 1980-ті рр. завдяки працям двох німецьких дослідників - протестанта Хайнца Шіллінга та католика Вольфганга Райнхарда. Конфесійна приналежність обох цих істориків визначала конфесійний об'єкт їхніх студій. У розроблених ними моделях було постульовано, що конфесіоналізація впливала на всі сфери життя ранньомодерного соціуму, хоч Хайнц Шіллінг звертав більшу увагу на культурно-соціальний вимір процесів, натомість Вольфганг' Райнхард зосередився на політико-державній перспективі й розгляді конфесіоналізації у контексті домодерних процесів модернізації та державотворення, коли релігійні аспекти в освіті, духовні практики, побожність слугували імпульсами до політичного розвитку (с. 24-26). Висновки Ірене Дінгель щодо можливостей використання парадигми конфесіоналізації у східнохристиянському контексті такі: хоч концепт «виріс» на матеріалі німецьких земель ранньомодерного часу, але досі залишається відкритим питання щодо особливостей його використання для інших теренів, особливо конфесій. Разом з тим, останні історіографічні напрацювання засвідчують перспективність цього концепту не лише при вивченні релігійно-державних процесів, але й культурної історії, зокрема, історії мистецтва, музики чи літератури. Позаяк конфесіоналізація неможлива без конфесійного будування (чи формування), це потребує комплексного вивчення, а також зумовлює розуміння особливостей досліджуваної релігійної спільноти (с. 43).

Наступний есей професора Альфонса Брюнінга з Інституту східного християнства в Університеті Неймегена ім. Радбода (Нідерланди) під назвою «Православ’я у конфесійну добу: від церковних реформ до конфесіоналізації? Спостереження у загальній церковно-історичній перспективі» ${ }^{1}$ найбільш пов'язаний з українським контекстом. За автором, концепт конфесіоналізації придатний не лише для вивчення церковної історії німецьких земель, але і для дослідження латинської Європи ранньомодерної доби загалом, наприклад релігійних процесів на французьких і скандинавських

${ }^{1}$ Це доповнений та уточнений варіант раніше публікованого тексту: Alfons Brüning, "Confessionalization in the Slavia Orthodoxa (Bielorussia, Ukraine, Russia)? Potential and Limits of a Western Historiographical Concept», in Religion and the Conceptual Boundary in Central and Eastern Europe, ed. by Thomas Bremer (London: Palgrave Macmillan, 2008), 65-96. 
землях, в Ірландії та Речі Посполитій (що стосується, серед іншого, й східнохристиянських конфесій) (с. 45). На прикладі Київської митрополії XVII ст., чи, за визначенням автора, церков візантійського обряду Східної Європи (die Kirchen des byzantinischen Ritus im Osten Europas), Альфонс Брюнінг представляє своє бачення процесів конфесіоналізації православних та унійної церков. Як він наголошує, його погляди розвивають один із західних концептів, що його вже було застосовано дослідниками (цю думку підкріплює короткий історіографічний огляд праць Сергія Плохія, Наталі Яковенко, Барбари Скіннер, Стефана Плагенборга та ін.) (с. 46). Автор показує перспективність парадигми конфесіоналізації для вивчення релігійних процесів у порівнянні з концептом о. Георгія Флоровського, який свого часу писав про «псевдоморфозу» Київської митрополії y XVII ст., коли латинська схоластика та освіченість видозмінили духовність митрополії, а також пропонував вивчати історію ранньомодерної Церкви в контексті «неопатристичного відродження» (с. 47). Розглядові «спроможності» концепту конфесіоналізації для вивчення історії православ’я у Східній Європі в рецензованому тексті передують роздуми автора про те, наскільки можна говорити про «православну конфесійну культуру» (orthodoxen Konfessionskultur) у тому розумінні «конфесійної культури», що його запропонував Томас Кауфман (с. 49) 2 .

Далі Альфонс Брюнінг окреслює хронологічні рамки та виокремлює періоди «конфесійної доби» (konfessionelles Zeitalter) у Східній Європі. На його думку, такими хронологічними межами виступають 1551 та 1721 роки. Ключовими маркерами для нижньої хронологічної цезури є собор у Москві 1551 р. та поява протестантів у Речі Посполитій упродовж 1550-х рр. Верхня межа - це початок синодального періоду в Московії та проведення Замойського синоду (c. 50). Зрештою, у ширшій перспективі в 1551 р. відбувались засідання Тридентського собору, а 1720 р. - кінець «конфесійної доби» для протестантів (за приклад узято м. Зальцбург). Наголошуючи на цьому, автор опосередковано поєднує релігійні процеси у православній Московії та в православній і унійній Київських митрополіях

${ }^{2}$ Детальніше про «конфесійну культуру» у ранньомодерну добу див.: Thomas Kaufmann, Konfession und Kultur. Lutherischer Protestantismus in der zweiten Hälfte des Reformationsjahrhunderts (Tübingen: Mohr Siebeck, 2006). 
(c. 51-53)3. Стосовно ж періодизації, то ії перший етап, за автором, завершується на початку XVII ст., і його знаменують діяльність гуртка в Острозькій академії, друкарська та освітня активність у Львові й Вільнюсі, а також полеміка довкола Берестейської унії. До 1620-х рр., на думку Альфонса Брюнінга, можна говорити про завершення першої фази «конфесійного будування» (с. 56).

Іншими словами, якщо доповнити Брюнінга, він має на увазі три варіанти - «московське православ'я», «київське православ'я» та «унійну модель». Для Унійної Церкви, як він наголошує, яскравим інституційним маркером стала реорганізація монашества та ухвали синоду у Кобрині 1626 р. Для Київської православної митрополії центр у цей самий час зміщується зі Львова та Вільнюса до Києва, де діяльність митрополита Петра (Могили) та його середовища сприяла формуванню «православної конфесії, що знайшло яскравий вияв у тексті «Православного ісповідання віри» (лат. Confessio Orthodoxa) 1643 p. (c. 57). На його думку, церковні баталії на українських теренах першої половини XVII ст. варто розглядати у зіставленні з релігійними війнами, що точилися тоді в латинській Європі. Загалом же для періоду 1551-1720 рр. найяскравішим прикладом східноєвропейської конфесіоналізації автор вважає співпрацю між козаками та єрархами Київської православної митрополії упродовж 1640-1650-х pp. (с. 58).

Інша теза дослідника полягає у тому, що до 1720 р. сформувалося три варіанти східнохристиянської традиції - унійна, православна (тут уже без розрізнення «московської» чи «київської») і старообрядницька. Понад те, на думку автора, конфесійні кордони було окреслено власне до 1720 р. не лише в ареалі латинського християнства, а й між трьома щойно згаданими варіантами східнохристиянської традиції, і це слугує важливим аргументом на користь існування процесів конфесіоналізації у Східній Європі (с. 61). Це знайшло прояв почасти в державній підтримці (чи їі відсутності), у внутрішній інституціоналізації, в уніфікації доктрини та своєрідній пропаганді серед вірних, а також у специфічній обрядовості (с. 60). Тобто йшлося про однакові зміни у різних церковних спіль-

${ }^{3}$ Пор. комплексну релігійну історію Східної Європи, у тому числі християнства, ісламу, юдаїзму тощо, подану у: Christoph Schmidt, Pilger, Popen und Propheten: Eine Religionsgeschichte Osteuropas (Paderborn: Ferdinand Schöningh, 2014). 
нотах - дисциплінуванні, освіті, катехизації тощо. Підсумовуючи свої спостереження, автор у висновках констатує придатність концепту «конфесіоналізації» до вивчення історії східнохристиянських традицій Східної Європи та підкреслює подібність ранньомодерних релігійних процесів як у латинському, так і в східному християнстві (c. 74).

У наступному есеї «Процес конфесіоналізації у православному християнському світі: спроба періодизації та систематизації» Васіліос Макрідес, професор релігійних студій з православ'я Ерфуртського університету, розглядає на теоретичному рівні проблеми конфесіоналізації з перспективи богослова. Насамперед він зауважує, що конфесіоналізм за своєю суттю означає фрагментацію та відособлення для християнської єдності (с. 78). Крім того, наголошено, що конфесійні процеси на православних територіях супроводжувала етніцизація та націоналізація (с. 98), для чого при розгляді цих процесів упродовж XIX ст. навіть ужито такі терміни, як «національна конфесіоналізація» (nationalen Konfessionalisierung) чи «етнічна конфесіоналізація» (etnische Konfessionalisierung) (c. 99). Підсумовуючи, автор підкреслює «іншість» православного контексту щодо цієї парадигми, хоч і наголошує на можливості ії̈ застосування при вивченні історії православних церков (с. 108-110).

Статтю з представленням процесів конфесіоналізації на балканських теренах (Греція, Сербія, Чорногорія, Болгарія, Боснія і Герцеговина) під назвою «Конфесіоналізація? Рефлексії щодо розвитку православ'я у Південній Європі до кінця XIX ст.» написав Клаус Бухенау, професор кафедри історії Південної і Східної Європи Регенсбурзького університету. Услід за істориком з Гайдельберзького університету Олафом Бляшке, автор розглядає XIX ст. як період «другої конфесіоналізації» (zweiten Konfessionalisierung) ${ }^{4}$ (с. 121). Насамперед дослідник відзначає європоцентричність (точніше західноцентричність) поглядів на конфесіоналізацію (с. 111) та наголошує, що коли й існують якісь особливі ознаки моделі релігійних процесів на німецьких землях, то це ще не означає, ніби йдеться не про конфесіоналізацію (с. 115). Іншу їі характерну рису він окреслює як демаркацію та уніфікацію, проте не конче в моноконфесійній

${ }^{4}$ Ідеться про статтю: Olaf Blaschke, «Das 19. Jahrhundert. Ein zweites konfessionelles Zeitalter?» Geschichte und Gesellschaft 26 (2000): 38-75. 
державі, адже це можна зауважити і на прикладі багатоконфесійної імперії. Наприклад, варто було 6 дослідити особливості таких процесів у Османській імперії, де домінантною релігією був іслам, а не християнство (с. 116). Описуючи особливості конфесіоналізації в балканських країнах, автор зауважує, що тамтешня еліта поєднувала націотворення з релігійним чинником. Окрім того, у різних балканських країнах процеси конфесіоналізації мали певні особливості. Так, якщо «пізня конфесіоналізація» у Воєводині розпочалася наприкінці XVII ст. та активізувалась упродовж XVIII ст., то в Боснії і Герцеговині схожі процеси простежуються лише з 1878 р. (c. 124). Зрештою, як наголошує автор, важливість церковного чинника у процесах націотворення призвів у Греції, Сербії, Румунії та Чорногорії до формування державних православних церков, що означало, своєю чергою, маргіналізацію інших конфесій чи релігій (c. 125). Більш того, за висновком дослідника, конфесіоналізація та націотворення були частково скоординованими процесами, які підтримували та зумовлювали одне одного (с. 127).

В емпіричній частині збірника уміщено вісім статей, 3-поміж яких у цьому огляді буде заторкнуто лише есеї, присвячені пізньому Середньовіччю та ранньомодерному періодові. Перші згадаю коротко. Міжконфесійні взаємини католиків і православних у Нікеї та Німфеї в 1234 р. описав Леоніе Екзархос з Університету ім. Георга-Августа у Геттінгені (с. 139-162). «Православну конфесіоналізацію» на основі аналізу патріарших реєстрів Константинополя XIV ст. представив д-р Крістіан Гастгебер з Інституту середньовічних студій (візантиністика) Австрійської академії наук у Відні (с. 163-188). Процеси конфесійної сегментації у XI-XIV ст. на румунських та прикарпатських теренах розглядає професор Кріст Зах з Інституту німецької культури та південноєвропейської історії Мюнхенського університету (с. 205-245). Становлення «конфесійного» православ'я у Волощині між XIV - початком XV ст., особливо у період господаря Нігоє Басараба (1512-1521), описує вже згадуваний д-р Михай ді Гріґоре (с. 247-263).

Що ж до розвідок про ранньомодерний час, то вони привертають більше уваги. Розпочати варто зі статті «Чи була конфесіоналізація у ранньомодерній Московії?» професора Яна Кусбера, спеціаліста зі східноєвропейської історії Університету ім. Йоганна Гутенберга у Майнці. Дослідник виділяє три проблеми для розгляду: 
рух до автокефалії Московської Церкви; розкол у середині XVII ст. та його наслідки; аналіз концепту конфесіоналізації у порівняльній перспективі. Особливо показовими в аспекті конфесіоналізації, на думку автора, є процеси другої половини XVII ст., коли царі використовували церковні інституції для соціального дисциплінування. Після анафеми старообрядців церква (за підтримки царів/ держави) посприяла маргіналізаціії та, ширше, й неможливості творення конкурентної конфесійної спільноти. Протопоп Аввакум, як пише автор, міг стати своєрідним Лютером для Московії, однак поява іншої конфесії, на відміну від латинської Європи, в умовах Московії була неможливою (с. 199-200). Ян Кусбер простежує формування моноконфесійності у Московській державі, згодом Російській імперії, від створення і легалізації патріархату та активної співпраці царя з церквою у другій половині XVII ст. аж до XIX ст., коли для імператора Миколи I православ’я та автократія виступали як неподільні, а багатоконфесійність була за означенням неможливою (с. 201). Таким чином, взаємини між царем та церквою, розглянуті автором з перспективи конфесіоналізації, а не церковної симфонії, дозволяють поглянути на досліджувані проблеми в інакшому ракурсі.

Релігійні процеси у Трансильванії (Семигородді) представляє у своїй статті д-р Едіт Шегеді з відділу міжнародних стосунків та німецьких студій Клузького університету імені Бабеша-Бойяї (Румунія). Крім викладу у хронологічній послідовності основних подій конфесійної історії ранньомодерного часу (с. 267-270), тут на прикладі біографій трьох церковних діячів - православного митрополита Симеона Штефана, кальвініста Йоана Зобу та радикального протестанта у вигнанні Михаїла Галічі - показано особливості різних конфесійних спільнот Трансильванії. Підкреслено, зокрема, що Галічі вважають першим, хто ідентифікував себе як румуна, але не пов'язував це з візантійською церковною традицією (тобто православ'ям) (с. 289-290). Завершує статтю висновок, що в ранньомодерній Трансильванії також сформувалася confessio orthodoxa (c. 290).

Процеси конфесіоналізації в Унійній Церкві Трансильванії ранньомодерної доби розглядає стаття професора східноєвропейської історії Ганса-Крістіяна Манера з Університету ім. Йогана Гутенберга у Майнці. Як показує дослідник, упродовж XVIII ст., 
після унії 1697 р., відбувалося формування унійної ідентичності. За доказ автор бере полемічні трактати 1750-1760-х рр. та активність основних тогочасних діячів. На його думку, власне полемічні тексти слугували ключовим чинником конституювання унійної ідентичності до кінця XVIII ст. (с. 299-302). Крім того, наголошено на тісному зв'язку конфесійного будування у тогочасній Трансильванії з позацерковною підтримкою, передусім державною (с. 303).

Завершує збірник стаття про конфесіоналізм у Румунії після Першої світової війни авторства д-ра Флоріана Кюерера-Віляха з Інституту німецької культури та південноєвропейської історії Мюнхенського університету. Зокрема, дослідник зауважує конфесійний чинник в інституційних перетвореннях та формуванні ідеї «Великої Румунії» із застосуванням концептів «трансконфесійності» та «внутрішньоконфесійності», а також прослідковує утвердження Православної Церкви як державної у Румунії міжвоєнного часу.

Завершуючи, варто підкреслити, що міждисциплінарний підхід різних дослідників до вивчення східнохристиянської традиції у контексті процесів конфесіоналізації на теренах Східної та Південної Європи засвідчує перспективність використання цієї парадигми, «відкриття» нових питань до вивчення релігійної культури, а також дозволяє побачити альтернативні варіанти інтерпретацій тих чи тих подій і явищ. Авторам рецензованого збірника вдалося показати придатність «західних» концептів конфесіоналізації (Konfessionalisierung) та конфесійного будування (Konfessionsbildung) для вивчення історії східнохристиянських церков - звісно, із врахуванням релевантності історичного контексту й розумінням специфіки православних та унійних еклезіальних спільнот.

\section{Bibliography}

Kaufmann, Thomas. Konfession und Kultur. Lutherischer Protestantismus in der zweiten Hälfte des Reformationsjahrhunderts. Tübingen: Mohr Siebeck, 2006.

Brüning, Alfons. «Confessionalization in the Slavia Orthodoxa (Bielorussia, Ukraine, Russia)? Potential and Limits of a Western Historiographical Concept.» In Religion and the Conceptual Boundary in 
Central and Eastern Europe, edited by Thomas Bremer, 65-96. London: Palgrave Macmillan, 2008.

Schmidt, Christoph. Pilger, Popen und Propheten: Eine Religionsgeschichte Osteuropas. Paderborn: Ferdinand Schöningh, 2014.

Blaschke, Olaf. «Das 19. Jahrhundert. Ein zweites konfessionelles Zeitalter?» Geschichte und Gesellschaft 26 (2000): 38-75. 